\section{Evaluating Soil Compaction with a Portable Electronic Cone Penetrometer}

\author{
Carl R. Crozier, ${ }^{1}$ \\ Ronnie W. H einiger, ${ }^{2}$ and \\ $M$ ichael Bishop ${ }^{3}$
}

AdDitional INDEX words. hardpan, crust, tillage pan, soil penetrometer resistance, soil strength

Summary. D uring Summer 1997, soil compaction in agricultural fields was evaluated using a portable electronic cone penetrometer. Rather than requiring the operator to read from an analog scale, this penetrometer stores data in a digital form, which are downloaded to a personal computer for analysis. Soil strength, measured in 1 -inch $(2.5-\mathrm{cm})$ increments, can be stored for up to 100 25-inch $(64-\mathrm{cm})$ deep soil profiles. This instrument can be operated by a single person and facilitates collecting large data sets required to characterize highly variable soil environments. Because the penetrometer was designed to measure and formulate predictions about the trafficability of wet soils, it is often incapable of measuring the higher soil resistance occurring in drier agricultural fields. If used soon after rainfall or irrigation, it is useful in detecting hardpans associated with tillage or traffic patterns.

Funding was provided by the $\mathrm{N}$ orth $\mathrm{C}$ arolina Soybean Growers Association, Inc. J. Cox, D. D avenport, M . Gibbs, P. M atthews, J. Smith, L. Smith, and J.L. Winslow assisted with site selection and data collection. Thanks to P. Puryear of the N .C. State U niv. Tobacco L iterature Service for library assistance. The penetrometer was supplied by the Division Chief, Mobility Systems Division, Geotechnical Laboratory, Waterways Experiment Station, U.S. Army Corps of Engineers, $3909 \mathrm{H}$ alls Ferry Rd., Vicksburg, M S 39180. $M$ ention of trade names does not constitute endorsement of any product or imply that other commercial products are less suitable.

${ }^{1} \mathrm{~N}$ orth C arolina State U niversity Soil Science D epartment and ${ }^{2} \mathrm{C}$ rop Science D epartment, Vernon G . J ames Research \& Extension Center, 207 Research Station Road, Plymouth, N C 27962.

${ }^{3} U$.S. Army Corps of Engineers, Waterways Experiment Station, Ecological Research-Wetlands, 3909 $\mathrm{H}$ alls Ferry Rd, Vicksburg, M S 39180.
$\mathrm{N}$

umerous studies describe the deleterious effect of compact soil horizonson crop root growth (Barber, 1971; U nger and Kaspar, 1994; Vepraskas, 1994). O bservations suggest that root systems of several vegetablecropscan belimited by compact soil layers (L orenz and M aynard, 1988; Portas, 1973). The numerous tillage and residue management options in use today have complex effects on soil properties. Tillage implements, vehicular traffic, and residuecover all affect soil strength. R esearch toolsare needed to evaluate how management schemes affect soil properties and crop performance.

Soil compaction can be inferred from measurements of bulk density, porosity, or penetrometer resistance (Chen and Tessire, 1997; Vepraskas, 1994). An advantage of using a penetrometer is that no soil removal is required. Because penetrometer resistance changes with soil wetness, soil moisture measurements are often necessary for data interpretation.

A variety of portable analog and digital soil penetrometers are available. The U .S. Army Corps of Engineers recently developed apenetrometer with featuresovercoming limitationsof other models used in agricultural systems. Goodman and R owse (1984) described a model with operating depth limited to 6 inches (15 cm), Reeves et al. (1992) used a benchtop rather than a portable model, Christensen et al. (1998) described a model which requires two operators, and H endrick (1969) described a model with an analog paper chart recorder. Anderson et al. (1980) described three models, one providing spuriousresultsdueto thespring mechanism, one vehicle-mounted unit with limited portability, and one similar to the model described here but requiring data to be transcribed from a calculator to a computer file. The penetrometer used in this study is designed for use by a single operator and stores data in a digital format. The objective of this research was to evaluate the usefulness of this portableelectronic penetrometer for characterization of compaction in agricultural soils.

\section{Materials and methods}

This study utilized a portable electronic penetrometer developed by the U.S. Army Corps of Engineers. Penetrometer resistance, up to $750 \mathrm{lb} /$ inch $^{2}(5.2 \mathrm{M} \mathrm{Pa}$ ) is measured by a load 


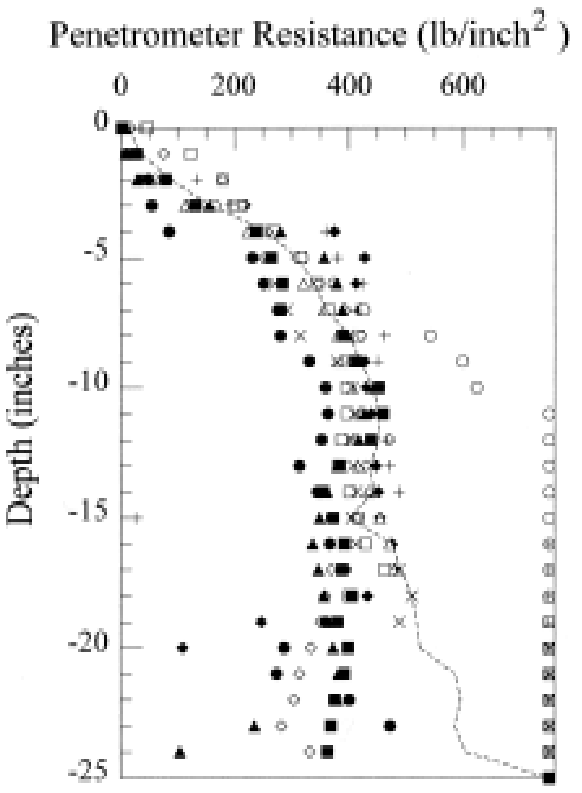

Fig. 1. Penetrometer resistance profiles from a wheel track within a single experimental plot at the Tidewater R esearch Station. Symbols represent individual data points for each of 10 profiles. The line indicates mean values for each 1 -inch $(2.5-\mathrm{cm})$ depth increment $\left(145 \mathrm{lb} /\right.$ inch $^{2}=1.0$ $\mathrm{MPa}$ ).

cell (model \#SSM-AJ-500, Interface, Scottsdale, Ariz.) connected to a tapered $\left(30^{\circ}\right.$ angle) probe with 0.2 -inch $^{2}$ $\left(130-\mathrm{mm}^{2}\right)$ cross-sectional area. A 0.5inch $^{2}\left(320-\mathrm{mm}^{2}\right)$ probe tip with a $30^{\circ}$ angle is also available. An electronic eye senses the vertical distance above the soil surface, and load cell distortion is used to calculate penetrometer resistance at each inch. A single operator pushes the penetrometer into thesoil by leaning on a metal handle. The device stores data for up to 100 25-inch (63$\mathrm{cm}$ ) deep soil profiles. Individual data points and averagesfor selected profiles are downloaded to a DOS-based personal computer. D ata are averaged for each 1 -inch $(2.5-\mathrm{cm})$ increment, for eight overlapping 4-inch (10-cm) increments ( 0 to 4,3 to 7,6 to 10,9 to 13,12 to 16,15 to 19,18 to 22 , and 21 to 25 inches), and for four overlapping 7 -inch $(18-\mathrm{cm}$ ) increments ( 0 to 7,6 to 13,12 to 19 , and 18 to 25 inches). D ata reported hereincludeboth 1-inch and 4-inch increments. With a portable computer, profile data can be viewed in the field. The penetrometer and portablebattery pack weigh $12.6 \mathrm{lb}(5.7 \mathrm{~kg})$ can be operated by a single person at a rate of about one profile per minute. A single operator weighing approximately $150 \mathrm{lb}(68 \mathrm{~kg})$ collected all data reported here.

D uring the summer of 1997, we measured soil penetrometer resistance at the Tidewater Research Station in Washington County, and at commercial farms in Beaufort and Perquimans Counties, N orth Carolina. At the Tidewater Research Station, penetrometer resistance was measured on along-term tillagestudy planted in soybean [Glycine $\max (\mathrm{L}$.) M err.]. This study had been established 15 years earlier on a Portsmouth finesandy loam (fine-loamy over sandy or sandy-skeletal, mixed, thermic Typic U mbraquults). Theexperimental layout wasarandomized completeblock design with four replicates, and $25 \times 50$ $\mathrm{ft}(7.6 \times 15-\mathrm{m})$ plots. For each comparison (dry vs. wet, crop row vs. tractor tire track, conventional till vs. notill), we probed five to ten subsamples per plot.

At the Beaufort County site, we sampled a soybean field on a T omotley fine sandy loam (fine-loamy, mixed, thermic Typic $O$ chraquults). Sixmonths before our measurements, a 24-inch $(61-\mathrm{cm})$ deep subsoil shank had been drawn through two areas of the field, each with four subsoil slits spaced $10 \mathrm{ft}$ (3 m) apart. Subsoil slit positions were evident from surfaceresiduedisturbance since there was no other tillage at this site. Twenty four subsamples were probed from each of the following situ- ations: subsoil slits, halfway between slits, and in surrounding areasat least 10 $\mathrm{ft}$ from the nearest slit.

At the Perquimans County site, adjacent conventional till and notill soybean fieldsonaScuppernongmuck (loamy, mixed, dysic thermic Terric M edisaprists) were sampled to assess compaction in vehicular turning zones. Surface drainage systems in this region result in long [ 5000 $\mathrm{ft}(1520 \mathrm{~m})$ ], narrow [ $300 \mathrm{ft}(91 \mathrm{~m})$ ] fields with restricted vehicletrafficpatterns. Eight subsamples were probed at locations 10 , $50,100,200$, and $300 \mathrm{ft}(3,15,30,61$, and $91 \mathrm{~m}$ ) from the field edge. Most turning occurs within $30 \mathrm{ft}(9 \mathrm{~m})$ of the field edge.

Statistical comparisons, where appropriate, were based on Fisher's protected LSD.

\section{Results and discussion}

The variable nature of soil penetrometer resistance requires large sample sizes for statistical inferences to be made (Fig. 1). This penetrometer is well-suited to collect such large data sets, and its digital format avoids the need for operators to read data from analog scales or to transcribe data (Anderson et al., 1980; H endrick, 1969). It is smaller and easier to move throughout a crop field than are electronic penetrometers used by Reeves et al. (1992) and C hristensen et al. (1998). Variability in resistance associated with operatorsand probespeedscan beminimized by using a single, attentive operator. Such variability is not necessarily a problem or limitation, it may merely require larger sample sizes for conclusive results. Calculations based on the variability presented in Fig. 1 suggest that this penetrometer ismost appropriate for field studies in which treatments of interesthavepenetrometer resistances which differ by at least $25 \%$ to $50 \%$ at the depth of interest ( $T$ able 1). At the inter-

Table 1. Estimates of the number of replicate penetrometer resistance profiles $(\mathrm{N})$ required to detect significant differences between treatments for different soil depths. C alculations are based on data presented in Fig. 1 (1 inch = $2.5 \mathrm{~cm}$; $\left.145 \mathrm{lb} / \mathrm{inch}^{2}=1.0 \mathrm{MPa}\right)$.

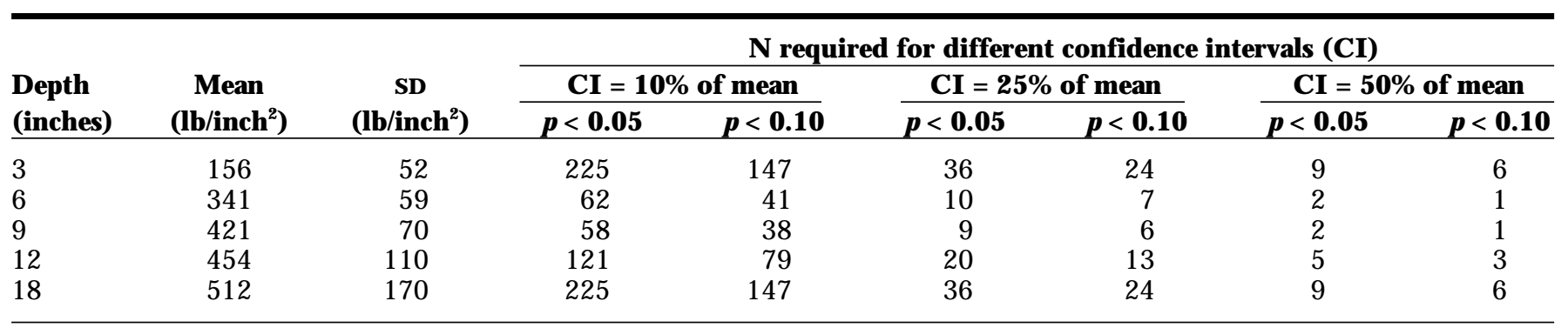

${ }^{2} \mathrm{~N}=\left[\mathrm{t}^{2}(\mathrm{sD})^{2}\right] / \mathrm{d}^{2}$, where $\mathrm{t}=$ student'st $(9 \mathrm{df})$ and $\mathrm{d}=$ half of desired confidence interval width [i.e., mean $\times(\%$ of mean/ 100) $\times 0.5]($ Steel and Torrie, 1980$)$. 
Penetrometer Resistance (lb/inch ${ }^{2}$ )

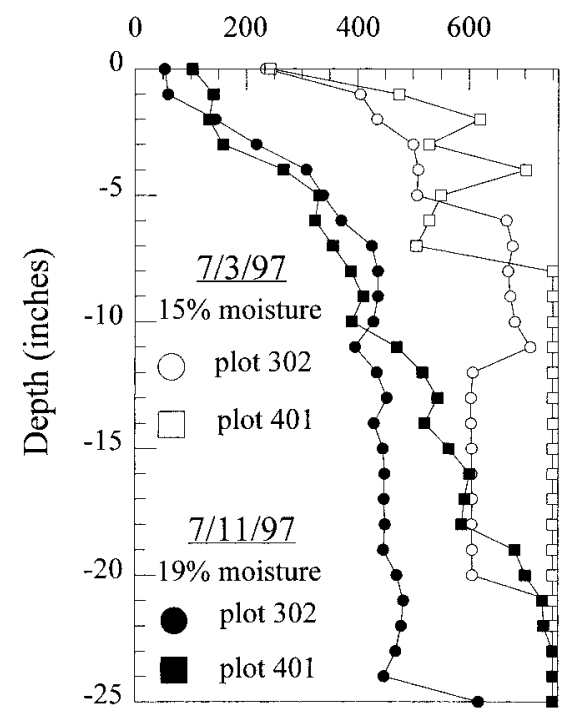

Fig. 2. Penetrometer resistance profiles from two experimental plots collected before ( 3 July 1997), and following (11 J uly 1997), irrigation and rainfall. Soil moisture was determined in the 0- to 6-inch (15$\mathrm{cm}$ ) depth increment (145 lb/inch ${ }^{2}=$ 1.0 $\mathrm{MPa}$ ).

Penetrometer Resistance (lb/inch ${ }^{2}$ )

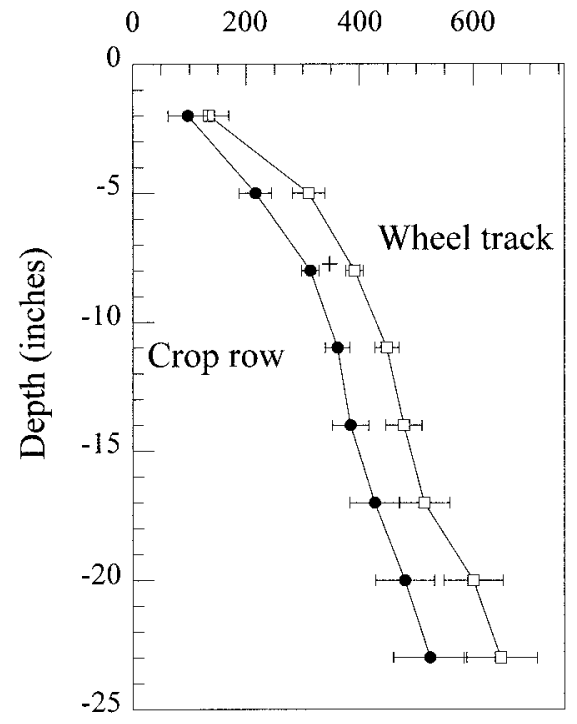

Fig. 3. Penetrometer resistance profiles from within wheel tracks and crop rows of conventionally tilled soybean research plots. Values plotted are means for $4-i n c h(10-\mathrm{cm})$ increments. Error bars indicate standard deviation, differences were significant $(p<0.1)$ at the 6- to 10 inch (15- to 25-cm) depth increment (145 lb/inch ${ }^{2}=1.0 \mathrm{MPa}$ ).
Penetrometer Resistance (lb/inch ${ }^{2}$ )

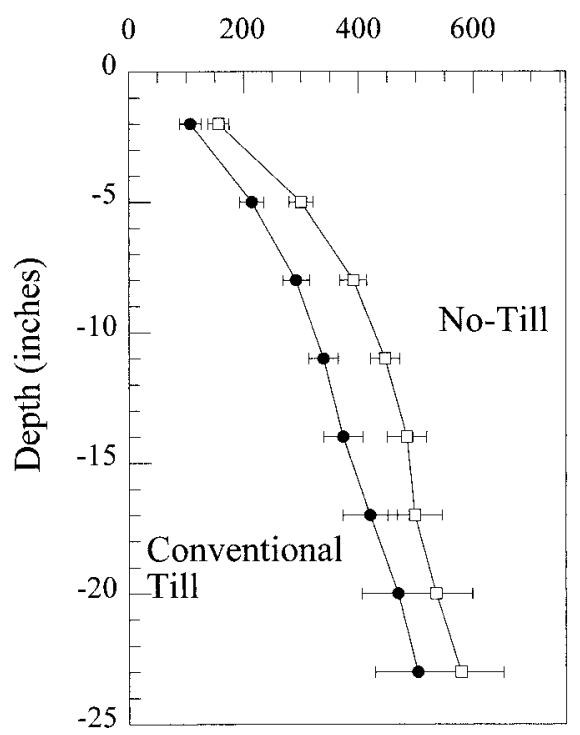

Fig. 4. Penetrometer resistance profiles from notill and conventionally managed soybean research plots. Values plotted are means for 4-inch increments. Error bars indicate standard deviation, differences were not significant at any depth ( $145 \mathrm{lb} /$ inch $^{2}=1.0 \mathrm{MPa}$ ).

Penetrometer Resistance (lb/inch ${ }^{2}$ )

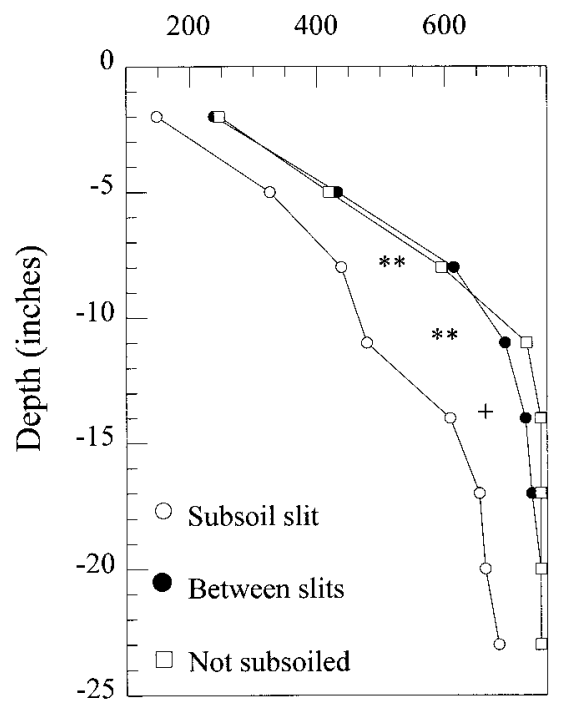

Fig. 5. Penetrometer resistance profiles from subsoil slits, areas located at the $5 \mathrm{ft}(1.5 \mathrm{~m})$ midpoint between slits ( between slits), and areas located at least $10 \mathrm{ft}(3 \mathrm{~m})$ from the nearest subsoil slit (not subsoiled). Values plotted are means for 4-inch $(10-\mathrm{cm})$ increments. Penetrometer resistance was significantly lower in the subsoil slits at the 6 - to 10 -inch (p $<0.01)$, 9- to 13-inch $(p<0.01)$, and 12- to 16 -inch $(p<0.1)$ depth incre ments $\left(145 \mathrm{lb} / \mathrm{inch}^{2}=1.0 \mathrm{MPa}\right)$.
Penetrometer Resistance (lb/inch $\left.{ }^{2}\right)$

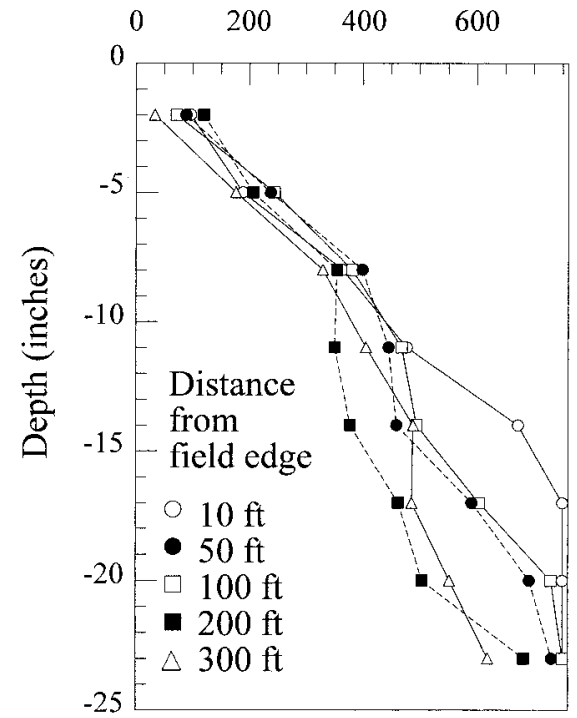

Fig. 6. Penetrometer resistance profiles from different locations in a notill soybean field indicating increased subsoil compaction near the more heavily trafficked edge. Values plotted are means for 4-inch $(10-\mathrm{cm})$ increments $\left(145 \mathrm{lb} / \mathrm{inch}^{2}=\right.$ 1.0 $\mathrm{MPa}$ ).

mediate soil depths where compaction is likely to occur ( 6 to 12 inches, 15 to $30 \mathrm{~cm}$ ), required samplesizesaresmaller than for either surface or deeper layers.

At theT idewater Research Station, penetrometer resistance was lower on 11 July, as a result of increased soil moisture due to irrigation and rainfall [1-inch $(2.5 \mathrm{~cm})$ ] following the 3 July sampling date (Fig. 2). Penetrometer resistancewashigher in tractor tiretracks than in crop rows, although differences were not significant except at the 6- to 10-inch (15- to 25-cm) depth increment ( $p<0.1$, Fig. 3). Penetrometer resistance washigher in the crop rows of long-term notill than in conventional till soybeans, although differences were not significant (Fig. 4).

At the Beaufort and Perquimans county sites, penetrometer resistance was lower in subsoil slits (Fig. 5), and higher in subsoils [ 12 to 19 inches (30 to $48 \mathrm{~cm}$ )] near the heavily trafficked edges of a notill field (Fig. 6). Fieldedgecompaction wasnot detected in an adjacent conventional ly tilled field (data not shown).

Although convenient to operate, this penetrometer has some limitations for agricultural field use. I t wasdesigned to make predictions about the trafficability of wet soils, and is often 
incapable of measuring the higher soil resistance occurring in drained agricultural fields. Themaximum resistancemeasured is $750 \mathrm{lb} /$ inch $^{2}(5.2 \mathrm{M} \mathrm{Pa})$, which was frequently exceeded for some soils (Figs. 1, 2, 5, 6). This limitation complicates data analysis, and may erroneously indicatetreatmentconvergenceattheupper limit. To minimizethis problem, the penetrometer should be used when soils are near in stu field capacity.

In summary, if sufficient samples are obtained to account for soil variability, and if soilsarenear field capacity, this instrument allows a single operator to quantify soil penetrometer resistance profiles in agricultural fields.

\section{Literature cited}

Anderson, G., J.D. Pridgeon, H .B. Spencer, and R. Parks. 1980. A new hand-held recording penetrometer for soil studies. J. Soil Sci. 31:279-296.

Barber, S. A. 1971. Effect of tillage practice on corn (Zea maysL.) root distribution and morphology. Agron. J. 63:724-725.

Chen, Y., and S. Tessier. 1997. Techniques to diagnose plow and disk pans. Can. Agr. Eng. 39:143-147.

Christensen, N.B., J.B. Sisson, D.W. Sweeney, and C.W. Swallow. 1998. Electronically-controlled, portable, cone penetrometer. Commun. Soil Sci. Plant Anal. 29:1177-1182.

Goodman, D., and H.R. Rowse. 1984. A combined penetrometer and surface relief meter for studying drill coulter performance. J. Soil Sci. 35:497-503.

H endrick, J.G. 1969. Recording soil penetrometer. J. Agr. Eng. Res. 14:183-186.

Lorenz, O. A., and D. N. M aynard. 1988. Knott's handbook for vegetable growers. 3rd ed. Wiley, N ew York.

Portas, C. M. 1973. Development of root systems during the growth of some vegetable crops. Plant Soil 39:507-518.

Reeves, D.W., H .H . Rogers, J .A. D roppers, S.A. Prior, and J.B. Powell. 1992. Wheeltraffic effectson corn asinfluenced by tillage system. Soil Till. Res. 23:177-192.

Steel, R.G.D ., and J.H . Torrie. 1980. Principles and procedures of statistics, a biometrical approach. 2nd ed. M cGraw-H ill, $\mathrm{N}$ ew York.

Unger, P.W. and T.C. Kaspar. 1994. Soil compaction and root growth: A review. Agron. J. 86:759-766.

Vepraskas, M .J. 1994. Plantresponsemechanisms to soil compaction, p. 263-287 In: R.E. Wilkinson (ed.). Plant-environment interactions. M arcel D ekker, Inc., N ew York. 